\title{
Formation of 5-formyl-2'-deoxycytidine from 5-methyl-2'-deoxycytidine in duplex DNA by Fenton-type reactions and $\gamma$-irradiation
}

\author{
Naoko Murata-Kamiya, Hiroyuki Kamiya1, Naoko Karino², Yoshihito Ueno², Hiroshi Kaji, \\ Akira Matsuda ${ }^{2}$ and Hiroshi Kasai ${ }^{1, *}$
}

Department of Health Policy and Management and ${ }^{1}$ Department of Environmental Oncology, Institute of Industrial Ecological Sciences, University of Occupational and Environmental Health, 1-1, Iseigaoka, Yahatanishi-ku, Kitakyushu 807-8555, Japan and ${ }^{2}$ Graduate School of Pharmaceutical Sciences, Hokkaido University, Kita-12, Nishi-6, Kita-ku, Sapporo 060-0812, Japan

Received August 10, 1999; Revised and Accepted October 1, 1999

\begin{abstract}
5-Methyl-2'-deoxycytidine (5-Me-dC) is formed by the enzymatic methylation of $\mathrm{dC}$, primarily in $\mathrm{CpG}$ sequences in DNA, and is involved in the regulation of gene expression. In the present study, 5-Me-dC and double-stranded DNA fragments containing 5-Me-dC were either $\gamma$-irradiated or aerobically treated with Fenton-type reagents, $\mathrm{Fe}$ (II)-EDTA, $\mathrm{Fe}$ (II)-nitrilotriacetic acid, $\mathrm{Fe}$ (III)-EDTA- $\mathrm{H}_{2} \mathrm{O}_{2}$-catechol or ascorbic acid- $\mathrm{H}_{2} \mathrm{O}_{2}$ under neutral conditions. The formation of 5-formyl-2'-deoxycytidine (5-CHO-dC) was observed upon treatment of both 5-Me-dC and DNA fragments containing 5-Me-dC. The yields of 5-CHO-dC from 5Me-dC and those of 5-formyl-2'-deoxyuridine from dT were comparable. These results suggest that 5-Me-dC in DNA is as susceptible to oxidation as dT in cells, and raise the possibility that $5-\mathrm{CHO}-\mathrm{dC}$ may contribute to the high mutagenic rate observed in $\mathrm{CpG}$ sequences in genomic DNA.
\end{abstract}

\section{INTRODUCTION}

5-Methyl-2'-deoxycytidine (5-Me-dC) is a minor component found in most eukaryotic DNA. In humans, $5 \%$ of all $\mathrm{dC}$ residues are enzymatically methylated. Methylation of $\mathrm{dC}$ occurs after DNA synthesis, primarily in $\mathrm{CpG}$ sequences $(1,2)$. The 5-Me-dC in a $\mathrm{CpG}$ sequence is involved in the regulation of gene expression (3-6) and the silencing of invading viral genomes $(7,8)$. Interestingly, $\mathrm{CpG}$ sequences are hot spots for mutations: the predominant mutation in the human p53 gene is a $\mathrm{C}$ to $\mathrm{T}$ transition in a $\mathrm{CpG}$ sequence $(9,10)$. This event has been thought to be the result of spontaneous or methylase-catalyzed hydrolytic deamination of 5-Me-dC to thymidine (11-13). However, this $\mathrm{C}$ to $\mathrm{T}$ transition could occur by other mechanisms as well as by the deamination of 5-Me-dC.

Recently, it was reported that UV-A irradiation of 5-Me-dC in the presence of a photosensitizer leads to the formation of various compounds, including 5-formyl-2'-deoxycytidine (5-CHO-dC)
(14). In addition, the formation of 5-formylcytosine was observed upon exposure of 5-methylcytosine to UV light (15). $5-\mathrm{CHO}-\mathrm{dC}$ in DNA may potentially be as miscoding and mutagenic as the dT analog, 5-formyl-2'-deoxyuridine (5-CHO-dU) (16-20). The presence of an intramolecular hydrogen bond between the carbonyl of the 5-formyl group and the 4-amino function may affect the equilibrium between the amino- and imino-tautomers. $(21,22)$. We supposed that the formation of $5-\mathrm{CHO}-\mathrm{dC}$ by reactive oxygen species (ROS) might be involved in the mutation process in the $\mathrm{CpG}$ sequences. Thus, it is important to know the formation rates of 5-CHO-dC from $5-\mathrm{Me}-\mathrm{dC}$ in various ROS-generating systems using Fentontype reactions, which are models for oxidation reactions in cells. In particular, an investigation of the formation of 5-CHO-dC in DNA is of great importance.

In the present study, 5-Me-dC and double-stranded DNA fragments containing $5-\mathrm{Me}-\mathrm{dC}$ were either $\gamma$-irradiated or aerobically treated with Fenton-type reagents [Fe(II)-EDTA, $\mathrm{Fe}$ (II)-nitrilotriacetic acid (NTA), $\mathrm{Fe}$ (III)-EDTA- $\mathrm{H}_{2} \mathrm{O}_{2}$-catechol or ascorbic acid- $\mathrm{H}_{2} \mathrm{O}_{2}$ ] under neutral conditions, and the formation of 5-CHO-dC from 5-Me-dC and that of 5-CHO-dU from dT were compared. We found that 5-CHO-dC was formed as efficiently as 5-CHO-dU, a major oxidation product of $\mathrm{dT}$, in the monomeric form and in DNA fragments. These results suggest that $5-\mathrm{CHO}-\mathrm{dC}$ may be formed in $\mathrm{CpG}$ sequences in cells and may induce $\mathrm{C}$ to $\mathrm{T}$ transition mutations.

\section{MATERIALS AND METHODS}

Nucleosides

The 5-CHO-dU standard was synthesized as described previously (16). The 5-CHO-dC (5) standard was prepared as shown in Scheme 1. Pd(II)-catalyzed vinylation of the 5-iodouracil derivative 1, followed by transformation of the 4-oxo group into an amino group using a known method, gave the 5-vinylcytosine derivative 3 in a $65 \%$ yield in two steps (23). Compound 3 was then converted to the 5-(1,2-dihydroxyethyl)cytosine derivative 4 in a $71 \%$ yield with $\mathrm{OsO}_{4}$ in the presence of $\mathrm{N}$-methylmorpholine $\mathrm{N}$-oxide. After deprotection of the TBS 
groups at the sugar moiety with $\mathrm{NH}_{4} \mathrm{~F}$ in $\mathrm{MeOH}$, the resulting nucleoside was treated with $\mathrm{NaIO}_{4}$ to give the desired 5-CHO$\mathrm{dC}(\mathbf{5})$ in a $92 \%$ yield as a crystalline product. Previously, the photosensitized oxidation of 5-Me-dC by 2-methyl-1,4-naphthoquinone was reported to give $\mathbf{5}$ in a $13 \%$ yield, which was assigned by NMR and mass spectrometric analyses (14), and these data are consistent with those of $\mathbf{5}$ described in this paper.

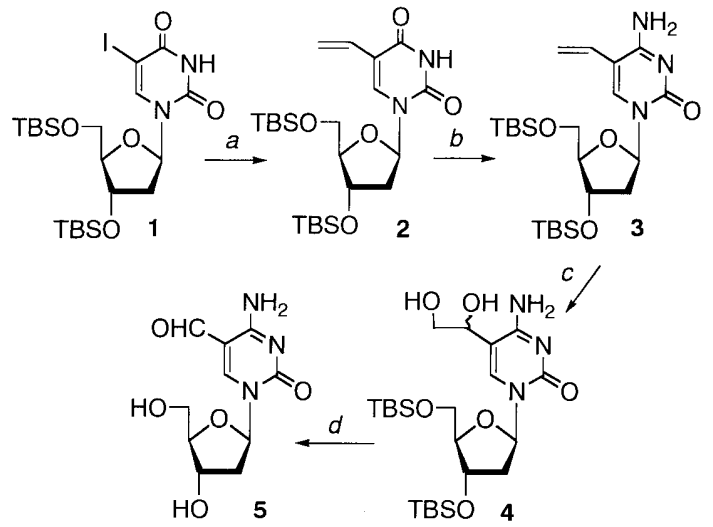

Scheme 1. Preparation of 5-CHO-dC; (a) tributyl(vinyl)tin, $\left(\mathrm{PPh}_{3}\right)_{2} \mathrm{PdCl}_{2}$, DMF, $80^{\circ} \mathrm{C}$; (b) (1) TPSCl, Et ${ }_{3} \mathrm{~N}$, DMAP, $\mathrm{CH}_{3} \mathrm{CN}$, (2) $25 \% \mathrm{NH}_{4} \mathrm{OH}$, room temperature, $65 \%$ from $1 ;$ (c) $\mathrm{OsO}_{4}, N$-methylmorpholine $\mathrm{N}$-oxide, aqueous acetone $+t-\mathrm{BuOH}$, room temperature, $71 \%$; (d) (1) $\mathrm{NH}_{4} \mathrm{~F}, \mathrm{MeOH}$, reflux, (2) $\mathrm{NaIO}_{4}, \mathrm{H}_{2} \mathrm{O}$, room temperature, $92 \%$.

3',5'-Bis-O-(tert-butyldimethylsilyl)-5-vinyl-2'-deoxycytidine (3). A mixture of $1(3.32 \mathrm{~g}, 5.69 \mathrm{mmol}),\left(\mathrm{Ph}_{3} \mathrm{P}\right)_{2} \mathrm{PdCl}_{2}(399 \mathrm{mg}$, $0.569 \mathrm{mmol})$ and tributyl(vinyl)tin $(2.00 \mathrm{ml}, 6.84 \mathrm{mmol})$ in DMF $(30 \mathrm{ml})$ was stirred at $80^{\circ} \mathrm{C}$ for $1.5 \mathrm{~h}$. The reaction mixture was filtered through a Celite pad, and the filtrate was taken up in EtOAc $(120 \mathrm{ml})$. The organic layer was washed with $\mathrm{H}_{2} \mathrm{O}(3 \times 40 \mathrm{ml})$ and brine $(40 \mathrm{ml})$, dried $\left(\mathrm{Na}_{2} \mathrm{SO}_{4}\right)$ and evaporated under reduced pressure. The residue was roughly purified by column chromatography $\left(\mathrm{SiO}_{2}, 5-20 \%\right.$ EtOAc in hexane) to give solids ( $2.40 \mathrm{~g}$ ) as a mixture of $\mathbf{2}$ and the tributyltin derivatives. A solution of the above solids $(2.40 \mathrm{~g}), \mathrm{Et}_{3} \mathrm{~N}$ (2.08 $\mathrm{ml}, 14.9 \mathrm{mmol})$, DMAP (1.82 g, $14.9 \mathrm{mmol})$ and 2,4,6triisopropylbenzenesulfonyl chloride $(4.51 \mathrm{~g}, 14.9 \mathrm{mmol})$ in $\mathrm{CH}_{3} \mathrm{CN}(40 \mathrm{ml})$ was stirred at room temperature for $24 \mathrm{~h}$. The mixture was cooled in an ice-bath. Concentrated $\mathrm{NH}_{4} \mathrm{OH}$ $(25 \%, 60 \mathrm{ml})$ was added, and the mixture was stirred at room temperature for $2 \mathrm{~h}$. The mixture was concentrated under reduced pressure and was taken up in EtOAc $(100 \mathrm{ml})$, which was washed with $\mathrm{H}_{2} \mathrm{O}(2 \times 40 \mathrm{ml})$ and brine $(40 \mathrm{ml})$. The separated organic layer was dried $\left(\mathrm{Na}_{2} \mathrm{SO}_{4}\right)$ and evaporated under reduced pressure. The residue was purified by column chromatography $\left(\mathrm{SiO}_{2}, 0-4 \% \mathrm{MeOH}\right.$ in $\left.\mathrm{CHCl}_{3}\right)$ to give $3(1.78 \mathrm{~g}, 65 \%$ from 1 as a foam): ${ }^{1} \mathrm{H} \mathrm{NMR}\left(270 \mathrm{MHz}, \mathrm{CDCl}_{3}\right) \delta 7.80(\mathrm{~s}, 1 \mathrm{H}, \mathrm{H}-6)$, 6.39-6.27 (m, 2H, H-1' and 5- $\left.\mathrm{CH}=\mathrm{CH}_{2}\right), 5.44\left(\mathrm{~d}, 1 \mathrm{H}, 5-\mathrm{CH}=\mathrm{CH}_{\mathrm{Z}}\right.$, $J=17.2 \mathrm{~Hz}), 5.30\left(\mathrm{~d}, 1 \mathrm{H}, 5-\mathrm{CH}=\mathrm{C} H_{\mathrm{E}}, J=11.2 \mathrm{~Hz}\right), 4.36$ (m, 1H, H-3'), 3.97 (m, 1H, H-4'), 3.87 (dd, 1H, H-5'a, $J=3.3$, $11.2 \mathrm{~Hz}), 3.76$ (dd, $\left.1 \mathrm{H}, \mathrm{H}-5^{\prime} \mathrm{b}, J=2.6,11.2 \mathrm{~Hz}\right), 2.48(\mathrm{ddd}, 1 \mathrm{H}$, H-2'a, $J=3.3,5.9,13.2 \mathrm{~Hz}$ ), 1.98 (ddd, $1 \mathrm{H}, \mathrm{H}-2^{\prime} \mathrm{b}, J=6.6,6.6$, $13.2 \mathrm{~Hz}$ ), 0.89 and 0.89 (each s, each $9 \mathrm{H}, \mathrm{Me}$ ), 0.08-0.06 $(\mathrm{m}, 12 \mathrm{H}, \mathrm{Me}) ; \mathrm{FABMS} \mathrm{m} / \mathrm{z} 482(\mathrm{M}+\mathrm{H})^{+}$; analysis calculated for $\mathrm{C}_{23} \mathrm{H}_{43} \mathrm{~N}_{3} \mathrm{O}_{4} \mathrm{Si}_{2}: \mathrm{C}, 57.34 ; \mathrm{H}, 9.00 ; \mathrm{N}, 8.72$. Found: $\mathrm{C}$, $57.11 ; \mathrm{H}, 8.84 ; \mathrm{N}, 8.47$.

3',5'-Bis-O-(tert-butyldimethylsilyl)-5-(1,2-dihydroxyethyl)-2'deoxycytidine (4). A solution of $\mathrm{OsO}_{4}$ in $t$ - $\mathrm{BuOH}(5 \mathrm{mg} / \mathrm{ml}$ in $t$-BuOH, $9.35 \mathrm{ml}, 0.184 \mathrm{mmol}$ ) was added to a solution of $\mathbf{3}$ $(1.77 \mathrm{~g}, 3.68 \mathrm{mmol})$ and $N$-methylmorpholine $N$-oxide $(647 \mathrm{mg}$, $5.52 \mathrm{mmol})$ in acetone- $\mathrm{H}_{2} \mathrm{O}-t-\mathrm{BuOH}(4: 1: 1,80 \mathrm{ml})$, and the resulting mixture was stirred at room temperature for $7 \mathrm{~h}$. After the reaction was quenched with saturated aqueous $\mathrm{Na}_{2} \mathrm{~S}_{2} \mathrm{O}_{3}$ $(20 \mathrm{ml})$, the mixture was extracted with EtOAc $(100 \mathrm{ml})$. The organic layer was washed with saturated aqueous $\mathrm{Na}_{2} \mathrm{~S}_{2} \mathrm{O}_{3}(2 \times$ $40 \mathrm{ml})$ and brine $(30 \mathrm{ml})$, dried $\left(\mathrm{Na}_{2} \mathrm{SO}_{4}\right)$ and evaporated under reduced pressure. The residue was purified by column chromatography $\left(\mathrm{SiO}_{2}, 0-10 \% \mathrm{MeOH}\right.$ in $\left.\mathrm{CHCl}_{3}\right)$ to give $4(1.36 \mathrm{~g}$, $71 \%$ as a foam): ${ }^{1} \mathrm{H}$ NMR $\left(270 \mathrm{MHz}, \mathrm{CDCl}_{3}\right) \delta 7.67$ and 7.65 (each s, $0.3 \mathrm{H}$ and $0.7 \mathrm{H}, \mathrm{H}-6), 6.23\left(\mathrm{~m}, 1 \mathrm{H}, \mathrm{H}-1^{\prime}\right), 4.58(\mathrm{~m}, 1 \mathrm{H}$, 5-CHOH), 4.34 (m, 1H, H-3'), 3.94 (m, 1H, H-4'), 3.87-3.72 (m, 4H, H-5'a,b and 5-CHOH-CH $\left.{ }_{2} \mathrm{OH}\right), 2.39\left(\mathrm{~m}, 1 \mathrm{H}, \mathrm{H}-2^{\prime} \mathrm{a}\right)$, $1.91\left(\mathrm{~m}, 1 \mathrm{H}, \mathrm{H}-2^{\prime} \mathrm{b}\right.$ ), 0.91 and 0.88 (each s, each $9 \mathrm{H}, \mathrm{Me}$ ), 0.10-0.06 (m, 12H, Me); HRMS (FAB) calculated for $\mathrm{C}_{23} \mathrm{H}_{46} \mathrm{~N}_{3} \mathrm{O}_{6} \mathrm{Si}_{2}$ 516.2925 (M+H) ${ }^{+}$, found 516.2935.

5-Formyl-2'-deoxycytidine (5). A mixture of $4(820 \mathrm{mg}, 1.59 \mathrm{mmol})$ and $\mathrm{NH}_{4} \mathrm{~F}(1.18 \mathrm{~g}, 31.9 \mathrm{mmol})$ in $\mathrm{MeOH}(20 \mathrm{ml})$ was heated under reflux for $16 \mathrm{~h}$ and was evaporated under reduced pressure. The residue was partitioned between $\mathrm{CHCl}_{3}(30 \mathrm{ml})$ and $\mathrm{H}_{2} \mathrm{O}$ $(50 \mathrm{ml})$. The aqueous layer was washed with $\mathrm{CHCl}_{3}(2 \times 30 \mathrm{ml})$ and was concentrated under reduced pressure. Sodium periodate $(680 \mathrm{mg}, 3.18 \mathrm{mmol})$ was added to the above solution, which was stirred at room temperature for $30 \mathrm{~min}$. After the reaction was quenched with saturated aqueous $\mathrm{Na}_{2} \mathrm{~S}_{2} \mathrm{O}_{3}(5 \mathrm{ml}), \mathrm{H}_{2} \mathrm{O}$ $(90 \mathrm{ml})$ was added to dissolve the precipitates. The mixture was absorbed onto an activated charcoal column, which was washed well with $\mathrm{H}_{2} \mathrm{O}$ and then with $50-100 \% \mathrm{MeOH}$ in $\mathrm{H}_{2} \mathrm{O}$ to give $\mathbf{5}$ (374 $\mathrm{mg}, 92 \%$ as a white powder, which was crystallized from $\mathrm{MeOH}$ ): no definite melting point (colored from 180 to $\left.300^{\circ} \mathrm{C}\right) ; \mathrm{UV}$ (MeOH) $\lambda_{\max } 283 \mathrm{~nm}$ (ع 11100$), 226 \mathrm{~nm}(\varepsilon 28700)$, $\lambda_{\min } 266 \mathrm{~nm}(\varepsilon 7400) ;{ }^{1} \mathrm{H}$ NMR (400 MHz, DMSO- $\left.d_{6}\right) \delta 9.39$ (s, 1H, CHO), 8.77 (s, 1H, H-6), 8.04 (br s, 1H, 4-NH, $\mathrm{D}_{2} \mathrm{O}$ exchangeable), 7.79 (br s, $1 \mathrm{H}, 4-\mathrm{NH}, \mathrm{D}_{2} \mathrm{O}$ exchangeable), 6.00 (t, $1 \mathrm{H}, \mathrm{H}-1^{\prime}, J=6.0 \mathrm{~Hz}$ ), 5.18 (br s, $2 \mathrm{H}, 3^{\prime}-5^{\prime}-\mathrm{OH}, \mathrm{D}_{2} \mathrm{O}$ exchangeable), 4.16 (m, $\left.1 \mathrm{H}, \mathrm{H}-3^{\prime}\right), 3.80$ (dd, $1 \mathrm{H}, \mathrm{H}-4^{\prime}, J=3.6$, $7.3 \mathrm{~Hz}), 3.61$ (dd, 1H, H-5'a, $J=3.6,12.0 \mathrm{~Hz}), 3.53(\mathrm{dd}, 1 \mathrm{H}$, $\mathrm{H}-5^{\prime} \mathrm{b}, J=3.9,12.0 \mathrm{~Hz}$ ), 2.24 (ddd, $1 \mathrm{H}, \mathrm{H}-2^{\prime} \mathrm{a}, J=4.8,5.6$, $13.1 \mathrm{~Hz}$ ), 2.03 (ddd, $1 \mathrm{H}, \mathrm{H}-2^{\prime} \mathrm{b}, J=5.9,6.6,13.1 \mathrm{~Hz}$ ); HRMS (FAB) calculated for $\mathrm{C}_{10} \mathrm{H}_{14} \mathrm{~N}_{3} \mathrm{O}_{5} 256.0933(\mathrm{M}+\mathrm{H})^{+}$, found 256.0920. Analysis calculated for $\mathrm{C}_{10} \mathrm{H}_{13} \mathrm{~N}_{3} \mathrm{O}_{5}$ : C, 47.06; $\mathrm{H}$, 5.13; N, 16.46. Found: C, 46.91; H, 5.07; N, 16.18.

\section{Oligonucleotides}

3'-O-[2-Cyanoethyl( $N, N$-isopropyl)phosphinyl]-5'-O-dimethoxytrityl- $N^{6}$-benzoyl-2'-deoxy-5-methylcytidine was prepared from 5-Me-dC using a known method $(24,25)$. Oligodeoxyribonucleotides containing 5-Me-dC were synthesized and purified as described previously (26). The following three self-complementary oligonucleotides were synthesized: $5^{\prime}$-dCGMGAATTMGCG-3' (Seq-1); 5'-dCGCGAATTMGCG-3' (Seq-2); and 5'-dCGMGAATTCGCG-3' (Seq-3) (M represents 5-methylcytosine). These were annealed to form duplexes before the treatments. 
Table 1. Yields of oxidized products formed by reactive oxygen species ${ }^{\mathrm{a}}$

\begin{tabular}{|c|c|c|c|c|}
\hline \multirow[t]{2}{*}{ Treatment } & \multicolumn{2}{|l|}{ Nucleosides } & \multicolumn{2}{|l|}{ DNA } \\
\hline & $5-\mathrm{CHO}-\mathrm{dC}$ & 5-CHO-dU & $5-\mathrm{CHO}-\mathrm{dC}$ & 5-CHO-dU \\
\hline $\mathrm{Fe}(\mathrm{II})-\mathrm{EDTA}^{\mathrm{b}}$ & $2.7 \pm 0.1$ & $4.1 \pm 0.1$ & $1.4 \pm 0.03$ & $1.6 \pm 0.1$ \\
\hline $\mathrm{Fe}(\mathrm{II})-\mathrm{NTA}^{\mathrm{c}}$ & $1.8 \pm 0.1$ & $2.7 \pm 0.1$ & $0.94 \pm 0.01$ & $1.3 \pm 0.1$ \\
\hline $\mathrm{Fe}(\mathrm{III})-\mathrm{EDTA}-\mathrm{H}_{2} \mathrm{O}_{2}$-catechol ${ }^{\mathrm{d}}$ & $5.8 \pm 0.2$ & $0.38 \pm 0.04$ & $1.3 \pm 0.1$ & $0.87 \pm 0.22$ \\
\hline \multicolumn{5}{|l|}{ Ascorbic acid- $\mathrm{H}_{2} \mathrm{O}_{2}{ }^{\mathrm{e}}$} \\
\hline $7.5 \mathrm{mM} \mathrm{H}_{2} \mathrm{O}_{2}$ & $0.35 \pm 0.03$ & $0.44 \pm 0.01$ & ND & ND \\
\hline $75 \mathrm{mM} \mathrm{H}_{2} \mathrm{O}_{2}$ & $0.67 \pm 0.18$ & $0.03 \pm 0.01$ & ND & ND \\
\hline$\gamma$-ray ${ }^{\mathrm{f}}$ & $0.97 \pm 0.04$ & $0.24 \pm 0.02$ & $1.4 \pm 0.1$ & $0.82 \pm 0.11$ \\
\hline
\end{tabular}

${ }^{a}$ Yields shown are the ratios (\%) of an oxidized nucleoside versus total (oxidized plus starting) nucleosides. The values represent the average of three separate experiments, with standard deviations.

${ }^{b}$ Nucleosides or a DNA fragment (Seq-1) were treated with Fe(II)-EDTA for $30 \mathrm{~min}$

'Nucleosides or a DNA fragment (Seq-1) were treated with Fe(II)-NTA for $30 \mathrm{~min}$.

${ }^{\mathrm{d} N u c l e o s i d e s}$ or a DNA fragment (Seq-1) were treated with $\mathrm{Fe}(\mathrm{III})$-EDTA- $\mathrm{H}_{2} \mathrm{O}_{2}$-catechol for $120 \mathrm{~min}$.

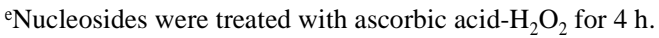

${ }^{\mathrm{f}}$ Nucleosides or a DNA fragment (Seq-1) were treated with $400 \mathrm{~Gy} \gamma$-ray irradiation.

$\mathrm{ND}$, not determined.

\section{Treatment of deoxyribonucleosides and double-stranded DNA fragments with Fenton-type reagents}

A single deoxyribonucleoside, dT or 5-Me-dC (1 mM), or a double-stranded DNA fragment $(11 \mu \mathrm{M})$ was treated with $\mathrm{Fe}(\mathrm{II})$-EDTA ( $5 \mathrm{mM} \mathrm{FeSO}_{4}$ and $5 \mathrm{mM}$ EDTA), $\mathrm{Fe}(\mathrm{II})$-NTA (5 $\mathrm{mM} \mathrm{FeSO}_{4}$ and $20 \mathrm{mM}$ NTA), $\mathrm{Fe}$ (III)-EDTA- $\mathrm{H}_{2} \mathrm{O}_{2}$-catechol $\left(0.1 \mathrm{mM} \mathrm{FeCl}_{3}, 0.5 \mathrm{mM}\right.$ EDTA, $5 \mathrm{mM} \mathrm{H}_{2} \mathrm{O}_{2}$ and $1 \mathrm{mM}$ catechol) or ascorbic acid- $\mathrm{H}_{2} \mathrm{O}_{2}(14.2 \mathrm{mM}$ ascorbic acid and 7.5 or $75 \mathrm{mM} \mathrm{H}_{2} \mathrm{O}_{2}$ ) in $50 \mathrm{mM}$ sodium phosphate buffer $(\mathrm{pH} \mathrm{7.0)}$ at $37^{\circ} \mathrm{C}$ (for deoxyribonucleosides) or $25^{\circ} \mathrm{C}$ (for DNA fragments) for the desired period of time. The $\mathrm{FeSO}_{4}$ solution was prepared immediately before addition to the other components. No $\mathrm{pH}$ change was observed either before or after the incubation.

\section{$\gamma$-Irradiation}

Irradiations of a single deoxyribonucleoside, $\mathrm{dT}$ or $5-\mathrm{Me}-\mathrm{dC}$ $(1 \mathrm{mM})$, or a double-stranded DNA fragment $(11 \mu \mathrm{M})$ in $50 \mathrm{mM}$ sodium phosphate buffer ( $\mathrm{pH}$ 7.0) were carried out with a Gammacell 40 Exactor with a ${ }^{137} \mathrm{Cs} \gamma$-ray source (Nordion International Inc.) at a dose rate of $1 \mathrm{~Gy} / \mathrm{min}$ (total 100-400 Gy).

\section{HPLC analysis}

Before the analysis by HPLC, the treated DNA fragments were purified with a Sep-Pak plus (Millipore) column. They were digested with snake venom phosphodiesterase $(0.15 \mathrm{U} / \mathrm{ml}$, Boehringer Mannheim) and calf intestine alkaline phosphatase (50 U/ml, Boehringer Mannheim) in $50 \mathrm{mM}$ HEPES-NaOH buffer ( $\mathrm{pH} 7.2)$ at $37^{\circ} \mathrm{C}$ for $2 \mathrm{~h}$. After the incubation, the reaction mixture was passed through a Micropure-EZ filter (Millipore) to remove the enzymes.

The resulting nucleoside mixture from the DNA fragments was injected into a reverse-phase HPLC column [YMC-pack ODS-AM303 $(4.6 \times 250 \mathrm{~mm})]$ connected with a photo-diode array UV detector (Hewlett Packard 1100 HPLC Detection System). In the case of 5-Me-dC or dT treated by ROS, the reaction mixture was injected directly. The following linear gradient of $\mathrm{CH}_{3} \mathrm{CN}$ concentrations in $10 \mathrm{mM} \mathrm{NaH} \mathrm{PO}_{4}(\mathrm{pH} 7.0)$ was used: $0-25 \mathrm{~min}$, linear gradient of $\mathrm{CH}_{3} \mathrm{CN} \quad(0-12.5 \%)$; 25-26 min, linear gradient of $\mathrm{CH}_{3} \mathrm{CN}(12.5-100 \%)$; and 26-31 min, $100 \% \mathrm{CH}_{3} \mathrm{CN}$. The flow rate was $1.0 \mathrm{ml} / \mathrm{min}$ and the column temperature was $25^{\circ} \mathrm{C}$.

The reactions and analyses were conducted in triplicate, and good reproducibilities were obtained.

\section{RESULTS}

\section{Treatment of deoxyribonucleosides and DNA fragments with Fe(II)-EDTA}

We first treated the nucleosides, 5-Me-dC and dT, separately with a Fenton-type reagent, Fe(II)-EDTA, and analyzed the reaction mixtures directly by reverse-phase HPLC. When 5-Me-dC was treated with $\mathrm{Fe}(\mathrm{II})-\mathrm{EDTA}$ at $37^{\circ} \mathrm{C}$ for $30 \mathrm{~min}$, a peak corresponding to 5-CHO-dC was detected (Fig. 1A). In the case of dT, 5-CHO-dU was identified as reported previously (27) (Fig. 1B). These assignments were made by comparison of their chromatographic and spectral properties with those of the standard samples.

We then examined the time course of 5-CHO-dC and 5-CHO-dU formation from 5-Me-dC and dT, respectively. 5-Me-dC or dT was treated with $\mathrm{Fe}$ (II)-EDTA at $37^{\circ} \mathrm{C}$ for $5,10,20$ and $30 \mathrm{~min}$. As shown in Figure 2, the yield of each oxidized product reached an almost maximal level after $5 \mathrm{~min}$. In this system, it is likely that auto-oxidation of $\mathrm{Fe}(\mathrm{II})$ to $\mathrm{Fe}$ (III) ions occurs within $5 \mathrm{~min}$. During the $30 \mathrm{~min}$ incubation, the yield of 5-CHO-dC reached 2.7\%, almost two-thirds that of 5-CHO-dU (Table 1).

Next, we treated a double-stranded DNA fragment (Seq-1) with Fe(II)-EDTA. This sequence is the same as that of Dickerson's dodecamer, which adopts the canonical B-DNA conformation (28-30) and contains four $\mathrm{CpG}$ sequences. We introduced 5-Me$\mathrm{dC}$ at positions 3 and 9 (Materials and Methods). We thought that this duplex would be a good model for methylated DNA. 

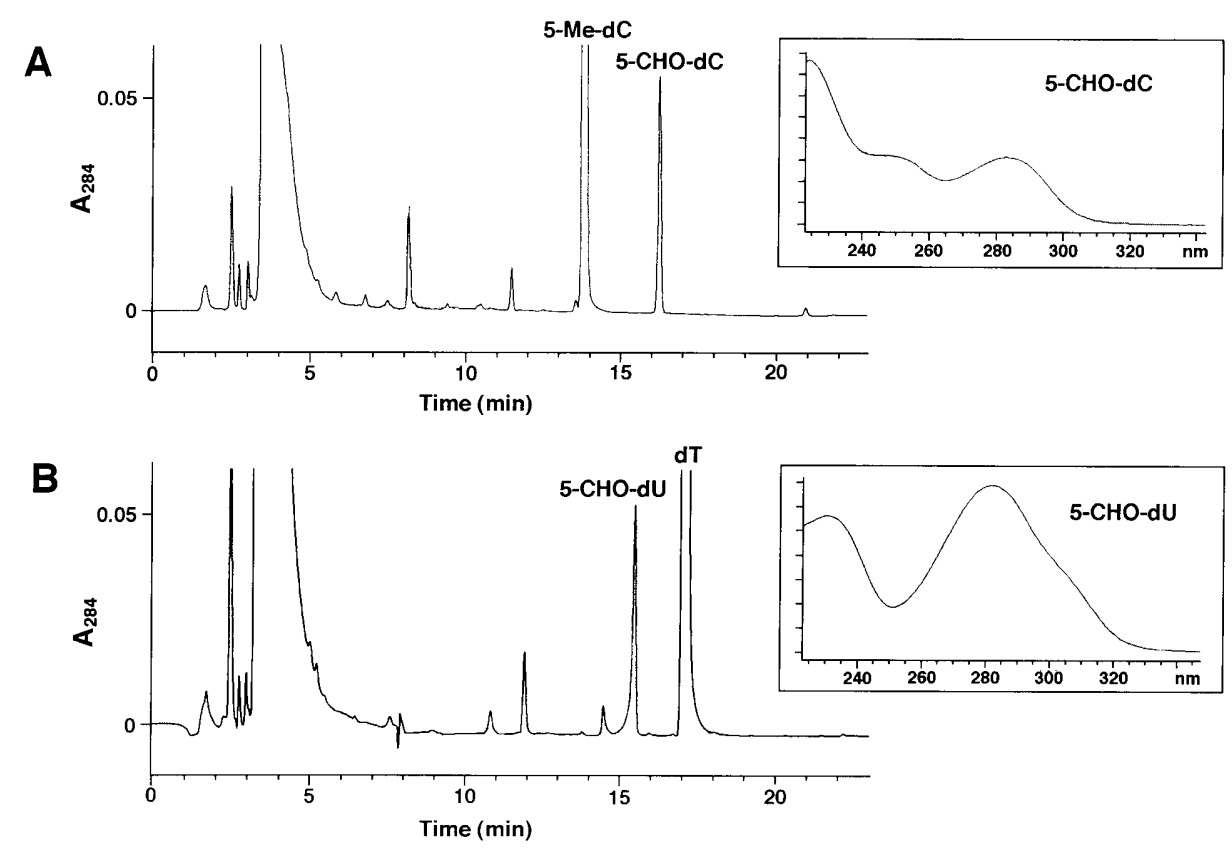

Figure 1. HPLC analysis of the reaction mixture of (A) 5-Me-dC and (B) dT with $\mathrm{Fe}(\mathrm{II})$-EDTA at $37^{\circ} \mathrm{C}$ for 30 min. The following linear gradients of $\mathrm{CH}_{3} \mathrm{CN}$ concentrations in $10 \mathrm{mM} \mathrm{NaH}_{2} \mathrm{PO}_{4}$ (pH 7.0) were used: 0-25 min, linear gradient of $\mathrm{CH}_{3} \mathrm{CN}(0-12.5 \%)$; 25-26 min, linear gradient of $\mathrm{CH}_{3} \mathrm{CN}(12.5-100 \%)$; 26-31 min, $100 \% \mathrm{CH}_{3} \mathrm{CN}$. Detection was performed with UV absorbance at $284 \mathrm{~nm}$. The UV spectra of 5-CHO-dC and 5-CHO-dU are also shown.

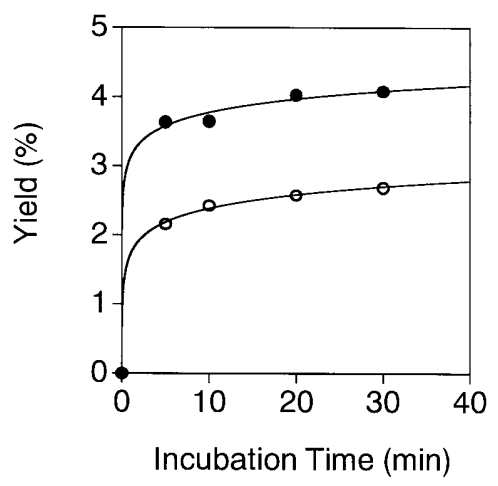

Figure 2. Time course of 5-CHO-dC (open circles) and 5-CHO-dU (closed circles) formation by $\mathrm{Fe}(\mathrm{II})$-EDTA from 5-Me-dC and dT, respectively. The 5-Me-dC and dT were treated as described in Materials and Methods.

When this DNA fragment was treated with Fe(II)-EDTA, and then digested by a nuclease and a phosphatase, the formation of 5-CHO-dC was observed. Thus, 5-CHO-dC was generated by the oxidation of 5-Me-dC in the DNA. The yield of 5-CHO-dC was similar to that of 5-CHO-dU. The yields of both products were higher in the monomeric form than in the DNA fragment.

To investigate whether 5-CHO-dC formation has sequence specificity, we compared the yields of 5-CHO-dC in the two DNA fragments, Seq-2 and Seq-3. Seq-2 has 5-Me-dC at position 9 (5'-TMG-3': M represents 5-Me-dC), whereas Seq-3 has 5-Me-dC at position $3\left(5^{\prime}-\mathrm{GMG}-3^{\prime}\right)$. The yields of $5-\mathrm{CHO}-\mathrm{dC}$ were $1.7 \%$ for Seq-2 and $1.3 \%$ for Seq-3. The yields of 5-CHO-dU were $2.2 \%$ for Seq-2 and 2.0\% for Seq-3. The ratios of 5-CHO-dC to 5-CHO-dU were 0.77 for Seq-2 and 0.65 for Seq-3, suggesting the absence of a neighboring base effect.

\section{Treatment of deoxyribonucleosides and a DNA fragment with $\mathrm{Fe}$ (II)-NTA}

We then treated the nucleosides and a double-stranded DNA fragment with $\mathrm{Fe}$ (II)-NTA. The formation of 5-CHO-dC and 5-CHO-dU was observed upon treatment of 5-Me-dC and dT, respectively, with Fe(II)-NTA (Table 1). These products were also detected when the duplex Seq-1 was treated with Fe(II)-NTA (Table 1). As with $\mathrm{Fe}$ (II)-EDTA, 5-CHO-dC was produced as efficiently as 5-CHO-dU.

\section{Treatment of deoxyribonucleosides and a DNA fragment with $\mathrm{Fe}$ (III)-EDTA- $\mathrm{H}_{2} \mathrm{O}_{2}$-catechol}

Next, we examined the time course of 5-CHO-dC and 5-CHO-dU formation from 5-Me-dC and dT, respectively, in another Fenton-type reaction. 5-Me-dC and dT were treated with $\mathrm{Fe}$ (III)-EDTA- $\mathrm{H}_{2} \mathrm{O}_{2}$-catechol at $37^{\circ} \mathrm{C}$ for $30,60,90$ and $120 \mathrm{~min}$. The Seq-1 duplex was tested similarly at $25^{\circ} \mathrm{C}$. As shown in Figure 3, the yield of each oxidized product increased in a time-dependent manner during the $120 \mathrm{~min}$ incubation, for both the nucleosides and the DNA fragment. With Fe(III)EDTA- $\mathrm{H}_{2} \mathrm{O}_{2}$-catechol, 5-CHO-dC was produced more efficiently than 5-CHO-dU (15-fold in the monomeric form and 1.5-fold in the DNA fragment) (Table 1). The yield of 5-CHO-dU was higher in DNA than in the monomeric form, whereas 5-CHO-dC was generated more efficiently in the monomeric form than in the DNA. 


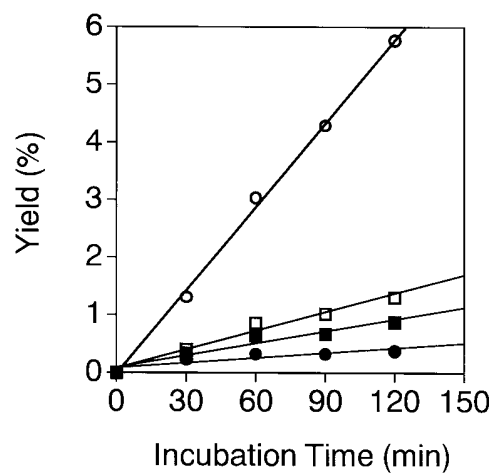

Figure 3. Time course of 5-CHO-dC (open circles) and 5-CHO-dU (closed circles) formation from 5-Me-dC and dT, respectively, and that of 5-CHO-dC (open squares) and 5-CHO-dU (closed squares) formation in duplex DNA by $\mathrm{Fe}$ (III)-EDTA- $\mathrm{H}_{2} \mathrm{O}_{2}$-catechol. The 5-Me-dC, dT and duplex DNA were treated as described in Materials and Methods.

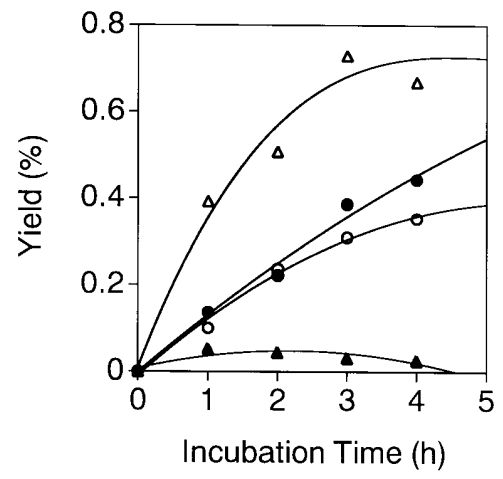

Figure 4. Time course of 5-CHO-dC (open circles) and 5-CHO-dU (closed circles) formation from 5-Me-dC and dT, respectively, by ascorbic acid-7.5 $\mathrm{mM} \mathrm{H}_{2} \mathrm{O}_{2}$, and that of 5-CHO-dC (open triangles) and 5-CHO-dU (closed triangles) formation from 5-Me-dC and dT, respectively, by ascorbic acid-75 $\mathrm{mM} \mathrm{H}_{2} \mathrm{O}_{2} .5-\mathrm{Me}-\mathrm{dC}$ and $\mathrm{dT}$ were treated as described in Materials and Methods.

\section{Treatment of deoxyribonucleosides with ascorbic acid- $\mathrm{H}_{2} \mathrm{O}_{2}$}

$5-\mathrm{Me}-\mathrm{dC}$ or dT was treated with ascorbic acid- $\mathrm{H}_{2} \mathrm{O}_{2}(14.2 \mathrm{mM}$ ascorbic acid and 7.5 or $75 \mathrm{mM} \mathrm{H}_{2} \mathrm{O}_{2}$ ) at $37^{\circ} \mathrm{C}$ for $1,2,3$ and $4 \mathrm{~h}$. With both concentrations of $\mathrm{H}_{2} \mathrm{O}_{2}$, the formation of 5-CHO-dC and 5-CHO-dU was observed. As shown in Figure 4, the yield of 5-CHO-dC increased in a time-dependent manner during a $4 \mathrm{~h}$ incubation with $7.5 \mathrm{mM} \mathrm{H}_{2} \mathrm{O}_{2}$. As in the case of 5-CHO-dC, the steady formation of 5-CHO-dU was observed with $7.5 \mathrm{mM}$ $\mathrm{H}_{2} \mathrm{O}_{2}$. However, the amount of 5-CHO-dU was decreased after $1 \mathrm{~h}$ with $75 \mathrm{mM} \mathrm{H}_{2} \mathrm{O}_{2}$. In the case of 5-CHO-dC, its yield increased up to $3 \mathrm{~h}$, and then decreased with $75 \mathrm{mM} \mathrm{H}_{2} \mathrm{O}_{2}$. Paradoxically, the yield of 5-CHO-dU was higher with the lower $\mathrm{H}_{2} \mathrm{O}_{2}$ concentration than with the higher $\mathrm{H}_{2} \mathrm{O}_{2}$ concentration, indicating that the 5-CHO-dU was degraded during the incubation with ascorbic acid-75 $\mathrm{mM} \mathrm{H}_{2} \mathrm{O}_{2}$. 5-CHO-dC was produced at least as efficiently as 5-CHO-dU by this type of treatment (Table 1).

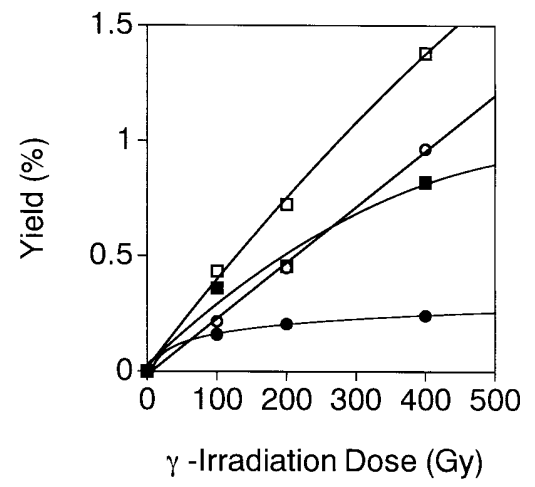

Figure 5. The formation of 5-CHO-dC (open circles) and 5-CHO-dU (closed circles) from 5-Me-dC and $\mathrm{dT}$, respectively, and that of 5-CHO-dC (open squares) and 5-CHO-dU (closed squares) in duplex DNA by $\gamma$-irradiation. The 5-Me-dC, dT and duplex DNA were exposed to $\gamma$-rays as described in Materials and Methods.

\section{Treatment of deoxyribonucleosides and a DNA fragment with $\boldsymbol{\gamma}$-rays}

Next, we tested whether 5-CHO-dC was generated by ionizing radiation. As expected, the formation of 5-CHO-dC and 5-CHO-dU was observed upon exposure of 5-Me-dC and dT, respectively, to $\gamma$-rays. As shown in Figure 5, the yield of each oxidized product increased up to $400 \mathrm{~Gy}$-irradiation. A linear increase in the formation of 5-CHO-dC was observed in the range 0-400 Gy. However, the formation of 5-CHO-dU from dT showed no linearity. Similar results were obtained when the DNA fragment, Seq-1, was $\gamma$-irradiated (Fig. 5). The yield of each oxidized product was higher in the DNA fragment than in the monomeric form. 5-CHO-dC was produced more efficiently than 5-CHO-dU.

\section{DISCUSSION}

In the present study, we investigated the formation of 5-CHO-dC from 5-Me-dC by Fenton-type reactions and $\gamma$-irradiation of both the monomeric form and duplex DNA fragments. We found that 5-CHO-dC was produced as efficiently as 5-CHO-dU. In particular, the formation of 5-CHO-dC was demonstrated, for the first time, in DNA fragments. The ratios of 5-CHO-dC to 5-CHO-dU differed, depending on the ROS-generating system used (Table 1). These results suggest that the ROS generated by these five reactions are not identical. Similar phenomena were observed for other oxidative products of DNA components (27).

Fenton-type reactions are models for oxidation reactions in cells. We found that 5-CHO-dC was formed with three Fenton-type reactions, $\mathrm{Fe}$ (II)-EDTA, $\mathrm{Fe}$ (II)-NTA and $\mathrm{Fe}$ (III)-EDTA- $\mathrm{H}_{2} \mathrm{O}_{2}$ catechol, under neutral conditions. With both $\mathrm{Fe}$ (II)-EDTA and $\mathrm{Fe}$ (II)-NTA, 5-CHO-dC was produced as efficiently as 5-CHO-dU (Table 1). With Fe(III)-EDTA- $\mathrm{H}_{2} \mathrm{O}_{2}$-catechol, 5-CHO-dC was produced more efficiently than 5-CHO-dU, especially in the monomeric form (Table 1). Because we previously found that 5-CHO-dU is generated more efficiently than 8-hydroxy-2'-deoxyguanosine (8-OH-dG) with Fenton-type reactions (27), 5-CHO-dC appears to be formed as efficiently as $8-\mathrm{OH}-\mathrm{dG}$. These results 
suggest that 5-CHO-dC is generated in cytosine methylation sites in cellular DNA by the endogeneous formation of ROS.

With ascorbic acid- $\mathrm{H}_{2} \mathrm{O}_{2}$, the ratio of 5-CHO-dC to 5-CHO-dU dramatically changed depending upon the $\mathrm{H}_{2} \mathrm{O}_{2}$ concentration. With $7.5 \mathrm{mM} \mathrm{H}_{2} \mathrm{O}_{2}$, the production of 5-CHO-dC was similar to that of 5-CHO-dU (Table 1). However, with $75 \mathrm{mM} \mathrm{H}_{2} \mathrm{O}_{2}$, the yield of 5-CHO-dC was 8- to 27-fold greater than that of 5-CHO-dU (Fig. 4). The fact that the yield of 5-CHO-dU was higher with 7.5 than $75 \mathrm{mM} \mathrm{H}_{2} \mathrm{O}_{2}$ suggests that the 5-CHO-dU was degraded under the more stringent conditions. 5-CHO-dU was produced as efficiently as 5-CHO-dC with $100 \mathrm{~Gy} \gamma$-irradiation. However, the relative yield of 5-CHO-dU to 5-CHO-dC was decreased with increased doses of irradiation (Fig. 5). Taken together, these results suggest that $5-\mathrm{CHO}-\mathrm{dU}$ was susceptible to further oxidation.

We found that 5-CHO-dC was formed as efficiently as 5-CHOdU. 5-CHO-dU has been detected in $\gamma$-irradiated DNA $(16,31)$. Mammalian and Escherichia coli cells possess repair activities for 5-CHO-dU (32-34). 5-Hydroxymethyl-2'-deoxycytidine, another type of oxidized 5-Me-dC, is present in calf thymus DNA (35), and a 5-hydroxymethylcytosine DNA glycosylase activity was found in mammalian tissue (36). Thus, it would be very interesting to determine whether $5-\mathrm{CHO}-\mathrm{dC}$ is formed and if repair activities for $5-\mathrm{CHO}-\mathrm{dC}$ are present in mammalian cells.

We supposed that 5-CHO-dC formation might be one cause of the $\mathrm{C}$ to $\mathrm{T}$ transition mutations frequently found in cytosine methylation sites. It was reported that an intramolecular hydrogen bond between the carbonyl of the 5-formyl group and the 4-amino function is present in the 5-formylcytosine moiety of its ribonucleoside $(21,22)$. The equilibrium between the amino- and imino-tautomers may be affected by this hydrogen bonding, and may allow the formation of a pair with adenine. This possibility and the recognition of 5-CHO-dC by DNA polymerases are of great interest.

\section{CONCLUSION}

5-CHO-dC was found to be formed from 5-Me-dC as efficiently as 5-CHO-dU from dT in duplex DNA under various oxidation reactions. This oxidation product of 5-Me-dC might be one cause of the mutations at cytosine methylation sites. We are currently investigating the mutagenicity of this oxidized base to understand its role in mutagenesis and carcinogenesis.

\section{ACKNOWLEDGEMENTS}

We would like to thank Dr Hiroshi Sugiyama of the Tokyo Medical and Dental University for his advice. This work was supported in part by a Grant-in-Aid from the Ministry of Education, Science, Sports and Culture, Japan.

\section{REFERENCES}

1. Razin,A. and Riggs,A.D. (1980) Science, 210, 604-610.

2. Verdine,G.L. (1994) Cell, 76, 197-200.

3. Cedar,H. (1988) Cell, 53, 3-4.

4. Hergersberg,M. (1991) Experientia, 47, 1171-1185.

5. Boyes,J. and Bird,A. (1991) Cell, 64, 1123-1134.

6. Barlow,D.P. (1993) Science, 260, 309-310.

7. Groudine,M., Eisenman,R. and Weintraub,H. (1981) Nature, 292, 311-317.

8. Doerfler,W. (1991) Biol. Chem. Hoppe Seyler, 372, 557-564.

9. Rideout,W.M.,III, Coetzee,G.A., Olumi,A.F. and Jones,P.A. (1990) Science, 249, 1288-1290.

10. Magewu,A.N. and Jones,P.A. (1994) Mol. Cell. Biol., 14, 4225-4232.

11. Shen,J.C., Rideout,W.M.,III and Jones,P.A. (1994) Nucleic Acids Res., 22, 972-976.

12. Wang,R.Y., Kuo,K.C., Gehrke,C.W., Huang,L.H. and Ehrlich,M. (1982) Biochim. Biophys. Acta, 697, 371-377.

13. Yebra,M.J. and Bhagwat,A.S. (1995) Biochemistry, 34, 14752-14757.

14. Bienvenu,C., Wagner,J.R. and Cadet,J. (1996) J. Am. Chem. Soc., 118, 11406-11411.

15. Privat,E. and Sowers,L.C. (1996) Chem. Res. Toxicol., 9, 745-750.

16. Kasai,H., Iida,A., Yamaizumi,Z., Nishimura,S. and Tanooka,H. (1990) Mutat. Res., 243, 249-253.

17. Ono,A., Okamoto,T., Inada,M., Nara,H. and Matsuda,A. (1994) Chem. Pharm. Bull. (Tokyo), 42, 2231-2237.

18. Yoshida,M., Makino,K., Morita,H., Terato,H., Ohyama,Y. and Ide,H. (1997) Nucleic Acids Res., 25, 1570-1577.

19. Zhang,Q.M., Sugiyama,H., Miyabe,I., Matsuda,S., Saito,I. and Yonei,S. (1997) Nucleic Acids Res., 25, 3969-3973.

20. Fujikawa,K., Kamiya,H. and Kasai,H. (1998) Nucleic Acids Res., 26, $4582-4587$.

21. Kawai,G., Yokogawa,T., Nishikawa,K., Ueda,T., Hashizume,T., McCloskey,J.A., Yokoyama,S. and Watanabe,K. (1994) Nucl. Nucl., 13, 1189-1199.

22. LaFrancois,C.J., Fujimoto,J. and Sowers,L.C. (1998) Chem. Res. Toxicol., 11, 75-83.

23. Sugiyama,H., Matsuda,S., Kino,K., Zhang,Q-M., Yonei,S. and Saito,I. (1996) Tetrahedron Lett., 37, 9067-9070.

24. Sinha,N.D., Biernat,J. and Koster,H. (1983) Tetrahedron Lett., 24, 5843-5846.

25. Atkinson,T. and Smith,M. (1984) In Gait,M.J. (ed.), Oligonucleotides Synthesis: A Practical Approach. IRL Press, Oxford, pp. 35-81.

26. Haginoya,N., Ono,A., Nomura,Y., Ueno,Y. and Matsuda,A. (1997) Bioconjug. Chem., 8, 271-280.

27. Murata-Kamiya,N., Kamiya,H., Muraoka,M., Kaji,H. and Kasai,H. (1997) J. Radiat. Res. (Tokyo), 38, 121-131.

28. Giessner-Prettre,C. and Pullman,B. (1982) Biochem. Biophys. Res. Commun., 107, 1539-1544.

29. Chen,Y.Z., Mohan, V. and Griffey,R.H. (1998) J. Biomol. Struct. Dyn., 15, 765-777.

30. Ikeda,H., Fernandez,R., Wilk,A., Barchi,J.J.,Jr, Huang,X. and Marquez,V.E. (1998) Nucleic Acids Res., 26, 2237-2244.

31. Douki,T., Delatour,T., Paganon,F. and Cadet,J. (1996) Chem. Res. Toxicol., 9, 1145-1151.

32. Bjelland,S., Birkeland,N.K., Benneche,T., Volden,G. and Seeberg,E. (1994) J. Biol. Chem., 269, 30489-30495.

33. Bjelland,S., Eide,L., Time,R.W., Stote,R., Eftedal,I., Volden,G. and Seeberg,E. (1995) Biochemistry, 34, 14758-14764.

34. Zhang,Q.M., Fujimoto,J. and Yonei,S. (1995) Int. J. Radiat. Biol., 68, 603-607.

35. Steinberg,J.J., Cajigas,A. and Brownlee,M. (1992) J. Chromatogr., 574, 41-55.

36. Cannon,S.V., Cummings,A. and Teebor,G.W. (1988) Biochem. Biophys. Res. Commun., 151, 1173-1179. 